\author{
Andrew Abbott, Mary Silles
}

Hull University Business School, University of Hull, Hull, UK

Corresponding author. Mary Silles, Hull University Business School, University of Hull, Cottingham Road, Hull, UK, HU6 7RX. Tel.: +44 (0)1482 463828, fax: +44 (0)1482 463484.

E-mail addresses: a.abbott@hull.ac.uk (A. Abbott),m.silles@hull.ac.uk (M.Silles)

\footnotetext{
* This paper has been accepted in June 2015 for publication in The World Economy.
} 


\title{
Determinants of international student migration
}

\begin{abstract}
This paper considers what factors determine the migration of overseas students, when students cross borders for higher education. We utilize a gravity model for international student mobility and derive estimates for a sample of 18 countries of destination and 38 countries of origin over the period 2005 to 2011. Our results confirm that geographical distance and the presence of a common language are powerful in explaining bilateral student flows. Our most interesting finding is that time zone differences have a statistically significant and economically large effect in determining international student flows.
\end{abstract}

Keywords: student mobility; migration; gravity equation; higher education

JEL classification: F22, I23, J24, J61 


\section{Introduction}

The empirical application of the gravity model to international trade has been extensive (e.g. Anderson and Van Wincoop, 2004; Linders, 2006; Disdier and Head, 2008), indicating that the amount of trade between two countries is proportional to their respective economic sizes and inversely related to the physical distance between them. This model has also been adapted to explain international migration (e.g. Beine et al., 2015; Bertoli and Fernández-Huertas Moraga, 2013; Lewer and Van den Berg, 2008). In this case, the flow of migrants between two countries is dependent upon the relative attractiveness of the countries of destination and origin (as measured by the difference in income levels); the population of the two countries ${ }^{1}$ and the costs of migration, which indicate the accessibility of the country of destination. Migration costs are assumed to be correlated with geographic distance between the two countries, so that ceteris paribus the greater the distance between two countries the lower will be the flows of migrants.

There is a growing empirical literature that attempts to identify the factors influencing bilateral migration flows using gravity-type models. For example, Lewer and Van den Berg (2008), consider the determinants of migrant flows into 16 OECD countries over the period 1991 to 2000. Their results show that physical distance has a negative effect on bilateral migration flows, so that the greater the costs of migration the lower the expected migration flows. The ratio of income for the destination to source countries has a small positive effect, so that higher relative incomes in countries of destination would be expected to draw more migrants. Positive effects on migration flows are also found from the stock of migrants from the country of origin currently located in the country of destination and the existence of a common language.

\footnotetext{
${ }^{1}$ Countries of origin with larger populations can potentially send more people, while larger countries of destination have potentially larger labour markets to absorb more migrants.
} 
Bertoli and Fernández-Huertas Moraga (2013) also find that GDP per capita for the country of origin has a statistically significant influence on bilateral migration flows to Spain and the estimated coefficient is negatively signed. This effect is even found after controlling for the potential effects of migration policy and Multilateral Resistance to Migration, which incorporates the attractiveness of alternative destinations. A similar approach is followed by Bertoli and Fernández-Huertas Moraga (2015).

Mayda (2010) finds that greater income opportunities in the country of destination raise migration flows, although surprisingly a similar positive effect is found from the GDP per worker of the country of origin. The log of distance is found to have a negative effect on migration flows as expected, though there is no role found for a common language variable, the presence of a common land border nor the existence of a former colonial relationship. The share of the young population in the country of origin is found to positively influence migration flows to the country of destination.

The focus of this paper lies in using the gravity model to explain international student mobility, whereby students cross borders for higher education. The number of international students has grown dramatically in recent decades. For example, in 1975 the number of students enrolled on programmes outside their country of citizenship was 0.8 million worldwide (OECD, 2013). This has since grown to 4.3 million in 2011. The number of overseas students doubled during the 2000s, averaging a growth rate of around $7 \%$. However, the pattern of student mobility is not uniform across countries (Perkins and Neumayer, 2014). For example, the G20 countries attracted around 83\% of the foreign students in 2011 and more than $50 \%$ of the students are enrolled in either Australia, Canada, France, Germany, the UK or United States (OECD, 2013). Among the countries of origin, China and India collectively account for more than $25 \%$ of the total students studying abroad, and Africa and 
Asia export more than $60 \%$ of foreign students. ${ }^{2}$ Thus understanding the factors driving the flow of students and the variability across country pairs is important.

The recent literature has identified a number of motivations for study abroad, including the desire of students to expand their knowledge of other societies and to improve their language skills, particularly English language (Kahanec and Králiková, 2011); opportunities for improved labour market outcomes from overseas higher education and the willingness of host countries to attract skilled labour (Beine et al., 2014; Chiswick and Miller, 2011). ${ }^{3}$ Student mobility has also been driven by the overall growth in higher education worldwide, particularly among high-income economies, and the perceived value of enrolling at prestigious institutions. This motivation has become even more important as students are aware of the perceived quality differences in higher education systems through the publication of institutional rankings (Perkins and Neumayer, 2014). For countries with smaller higher education sectors, inward student mobility also provides the opportunity to expand provision and potentially exploit economies of scale (OECD, 2013).

An emerging literature has attempted to identify the determinants of international student mobility. For example, Beine et al. (2014) consider inflows from a wide set of origin countries into 13 OECD economies from 2004 to 2007. Migration costs, as proxied by physical distance, are found to have a statistically significant and negative effect on international student mobility. Common language and the presence of a strong network of migrants in the country of destination positively influence international student migrant flows. Academic quality is also found to positively influence mobility, while higher living costs deter potential student migrants. The finding of improved rankings positively

\footnotetext{
${ }^{2}$ OECD (2013) also note the importance of regional student mobility over global mobility, particularly within the Asia-Pacific region. Within the European Union, government policy has facilitated student flows through the Erasmus programmes.

${ }^{3}$ Dreher and Poutvaara (2005) also find a close link between student flows and migration flows, with a 10 per cent increase in student flows leading to between a 0.3 and 0.9 per cent increase in migration into the USA from 78 countries of origin over the period 1971 to 2001.
} 
influencing mobility is in contrast to the results of Perkins and Neumayer (2014), who find a comparatively small influence from university quality, measured through competitive rankings. However, the standard gravity variables are found to be statistically significant and the estimates correctly signed, with migration costs found to be a bigger deterrent to mobility of students originating from developing countries than high-income countries. ${ }^{4}$

Agasisti and Dal Bianco (2007) also show that distance plays a negative role with respect to student mobility across the regions of Italy. Their findings suggest that enrolments are influenced by university characteristics, such as the number of faculties and the amount of student aid, as well by the economic characteristics of the region in which the university is located. Focussing only on Germany, Bessey (2012) investigates inward student mobility from 147 countries over the period 1997 to 2002. The results present a fairly stable picture that geographic distance acts as a migration cost, while population of the originating country positively influences student migration flows to Germany.

Interestingly, Jena and Reilly (2013) consider the demand for UK higher education overseas by considering what factors influence the number of visas issued to study in the UK. They find an important role for the exchange rate but interestingly the real visa cost has no significant impact on visa numbers ${ }^{5}$ nor the log of per capita income in the country of origin. Distance again is statistically significant and acts as a migration cost, while the UK has issued more visas to countries that share the common language.

In this paper, we investigate the determinants of international student mobility for a sample of 18 countries of destination and 38 countries of origin over the period 2005 to 2011. Our approach adds to the existing literature in a number of respects. Firstly, we use a large panel of countries of origin and destination, which covers a range of high income and non-

\footnotetext{
${ }^{4}$ The benefits of a common language are also greater for those students originating from a developing country, while surprisingly income differentials between the countries of destination and origin are found to have a negative effect on student migration.

${ }^{5}$ A result explained by the relatively small cost of visas compared to the total cost of study.
} 
high income economies. This enables us to cover the most important bilateral student migration flows across a broad spectrum of countries. We provide separate estimates for inflows from both the high and non-high income countries. Our sample period of 2005 to 2011 is more recent than earlier studies ${ }^{6}$, allowing us to encompass the influence of recent economic events, for example, the effects of the recent financial crisis on international student mobility. As well, we are able to control for unobserved cross country heterogenity through the inclusion of country of fixed effects for the countries of origin and the countries of destination. This is important when we reflect on the uneven pattern of student mobility that exists across different countries of origin and destination.

Secondly, to our knowledge, this is the first paper that tests whether migration costs can also be proxied through the time difference between two countries rather than physical distance. Time difference could be a deterrant to mobility since it acts as a barrier to communication, since opportunities to maintain contact with friends and family are reduced the greater the time difference between two countries. Our results suggest that time difference has a statistically significant and negative effect on the movement of international students.

Finally, this literature has relied on conventional estimators, such as OLS or panel data estimators e.g. fixed effects. However, in the presence of zero values (e.g. due to missing values or when there is no migration (student mobility)) OLS estimators are not efficient. In this case, it is desirable to adopt the Poisson Pseudo Maximum Likelihood (PPML) estimator (see Santos Silva and Tenreyo, 2006; 2011). We adopt this procedure for the estimtion of all our regression models.

\footnotetext{
${ }^{6}$ For example, Perkins and Neumayer (2014) estimate their model from 2004 to 2009, Bessey uses data from 1997 to 2002
} 
The remainder of the paper is organized as follows. Section two describes the model and data. Section three discusses the estimation results, while section four contains concluding remarks.

\section{Model and Data}

To investigate the determinants of international student mobility we use:

$$
\begin{aligned}
& \ln \left(S_{o d t}\right)=\lambda_{t}+\phi_{o}+\phi_{d}+\delta_{1}\left(\frac{G D P p c_{d t}}{G D P p c_{o t}}\right)+\delta_{2} \ln \left(\text { dist }_{o d}\right)+\delta_{3} \operatorname{cont}_{\text {od }}+\delta_{4} \operatorname{lang}_{\text {od }}+\delta_{5} \operatorname{col}_{\text {od }} \\
& +\delta_{6} E U_{o d}+\delta_{7} \ln \left(\operatorname{rank}_{d t}\right)+\delta_{8} \ln \left(\text { outbd }_{o t}\right)+\delta_{9} \ln \left(R E R_{o d t}\right)+\varepsilon_{o d t}
\end{aligned}
$$

The variables used, together with the data sources, are described in appendix A. $S_{\text {odt }}$ is the flow of students from a country of origin $o$ to a country of destination $d$ at time $t$. The student flow consists of the number of persons who left their country of origin and moved to another country for the purpose of study. We therefore exclude students who are not citizens of the countries where they are enrolled but are long-term residents or were born in the country of

destination. $\left(\frac{G D P p c_{d t}}{G D P p c_{o t}}\right)$ is the ratio of real GDP per capita for the country of destination relative to the GDP per capita for the country of origin. This accounts for the wage differential between the two economies and the economic incentive faced by potential student migrants, so that we expect $\delta_{1}>0$. The geographic distance between the two countries is denoted by dist ${ }_{\text {od }}$, measured by the Great Circle distance in kilometres between the two countries, using the most important city (in terms of population) or the official capital city. If distance acts as a migration cost then we expect $\delta_{1}<0$. Student flows are also likely to be 
greater between country pairs that are adjacent to one another. ${ }^{7}$ We therefore account for the presence of a common land border through the binary variable cont $_{\text {od }}$ that equals one for contiguous country pairs, expecting $\delta_{3}>0$. The language spoken in the country of destination and used in instruction can determine which country students choose. Countries whose languages are widely spoken are likely to be leading destinations and given the progressive adoption of English as a global language, it is not surprising the majority of English speaking countries are popular destinations. Nevertheless, learning a foreign language may still act as a barrier to mobility, so we add the binary variable lang $_{\text {od }}$ that equals unity for the country pairs that have a common language, assuming $\delta_{4}>0 .{ }^{8}$ The standard gravity control variable, former colonial relationships, is added denoted by $\operatorname{col}_{\text {od }}$ and $\delta_{5}$ should be positive. In the trade literature, colonial relationships are expected to boost trade through encouraging commonality of institutional frameworks, which add to the security of transactions and lower communication costs, as well leading to the development of trade networks which last even after the colonization has ended (Disdier and Mayer, 2007). Colonial relationships could be expected to boost student mobility given the large migrant populations located in the recipient countries. Moreover, intergovernmental policy can encourage student mobility e.g. the UK government offers a series of Commonwealth Scholarships for study. The dummy variable $E U_{\text {od }}$ is included since student mobility is expected to be greater among pairs of countries where both are members of the European Union. There are no visa restrictions limiting the movement of EU nationals and student mobility is strongly encouraged through the various Erasmus mobility programmes, which provide considerable financial assistance for study abroad, predominantly within Europe, so $\delta_{6}$ is expected to be positive. Students

\footnotetext{
${ }^{7}$ OECD (2013) note that in 2011 on average 21\% of foreign students came from countries of origin that share land or maritime borders with the country of destination.

${ }^{8}$ We can classify a common language when both countries speak a common official language or when a given proportion of the population speaks the same language. Here we define a common language as existing whenever a language is spoken by at least $9 \%$ of the population in both countries (Mayer and Zignago, 2011).
} 
increasingly select their destination based on the perceived quality of the education being offered (Kahanec and Králiková, 2011; OECD, 2013). More students are expected to be drawn to countries with more highly-ranked institutions, which is defined as the mean institutional ranking of the country of destination. We therefore add $\ln \left(\operatorname{rank}_{d t}\right)$ to encompass the reputation of a destination country's universities. Lower values of $\ln \left(\operatorname{rank}_{d t}\right)$ imply a higher ranking, so $\delta_{7}$ should be negative. The importance attached to outward student mobility in a country of origin can also influence bilateral student flows. Students may be encouraged to study abroad if many more of their fellow students do so. We therefore add $\ln \left(\right.$ outbd $\left._{\text {ot }}\right)$ the total number of outbound students from the country of origin, expecting $\delta_{8}$ to be positive. Finally, $\ln \left(R E R_{\text {odt }}\right)$, the real exchange rate, is defined as the price of foreign currency in terms of domestic currency. A higher price of foreign currency increases the cost of tuition and maintenance, thus deterring student mobility, so $\delta_{9}$ should be negative. $\phi_{0}$ and $\phi_{\mathrm{d}}$ denote country of origin and country of destination fixed effects that account for unobservable heterogeneity in student flows ${ }^{9}$ while $\lambda_{\mathrm{t}}$ represent time effects, and $\varepsilon_{\text {odt }}$ is a white noise error term.

We focus our analysis on students who left their country of origin to study abroad. Students who are foreigners but reside in the country of destination are therefore excluded from the analysis. Taking data from 2005 to 2011 the sample includes 18 countries of destination ${ }^{10}$ and 38 countries of origin, ${ }^{11}$ which yields 2,286 observations spanning bilateral

\footnotetext{
${ }^{9}$ The country of destination effects can pick up influences on student mobility coming through, for example, the language of the country. Countries whose official language is English would be expected to be more attractive student destinations. Country of origin fixed effects could account for the uneven pattern of student mobility across different countries of origin due to different economic incentives to study abroad. An alternative would be to use country-pair fixed effects but this would exclude the time-invariant variables from our model (e.g. distance), which are the focus of our study.

${ }^{10}$ Australia, Belgium, Canada, Chile, Denmark, Estonia, Germany, Hungary, Ireland, Netherlands, New Zealand, Portugal, Slovenia, Spain, Sweden, Switzerland, United Kingdom, United States.

${ }^{11}$ The countries of origin sample includes all 18 destination countries plus Argentina, Austria, Brazil, China, Czech Republic, Finland, France, Greece, Iceland, India, Indonesia, Israel, Italy, Japan, South Korea, Mexico, Norway, Poland, Slovak Republic, Slovenia and Russia.
} 
flows over 2005-2011 for 606 pairs of countries. The countries are chosen based on the available sample from our data source.

Table 1 provides the distribution of student flows across the main countries of origin, with the ten largest source countries listed. China and India clearly dominate, together accounting for more than $40 \%$ of outward student mobility, a factor driven in part by their very large populations and rapid economic development over the last few decades. Collectively the ten countries listed account for about $80 \%$ of the outward student flows. Seven of them are high-income countries.

\section{TABLE 1 NEAR HERE}

The top ten countries of destination are listed in table 2 together with the number of students enrolled and the student flow as a percentage of the total. Not surprisingly the top three countries of destination are all English speaking countries, showing the importance of the English language as an attractor for outbound students. The USA clearly dominates as the main country of destination, accounting for over $45 \%$ of the total inward student flow. However, it is the largest country by population and therefore the potential to accommodate many more students. Among the non-English speaking countries Germany appears a particularly attrractive destination.

\section{TABLE 2 NEAR HERE}

\section{Results}

This section reports the results of our study using the Poisson Pseudo Maximum Likelihood (PPML) estimator recommended by Santos Silva and Tenreyo (2006, 2011). Santos Silva and Tenreyo (2006) show that heteroskedasticity can cause the OLS estimator to yield biased estimates. However, the PPML estimator is consistent in the presence of heteroscedasticity 
and provides a way to deal with zero values of the dependent variable. ${ }^{12}$ All regressions include controls for country of origin and country of destination fixed effects to account for country-specific factors that do not change over time. These parameters are not reported. ${ }^{13}$ Instead attention is focused on the effects of the key variables that describe the costs and benefits of studying abroad. Table 3 presents the results for all countries in our sample. The fit of our model is good with an $R^{2}$ of 0.92 , suggesting that the model is suitable for analyzing patterns of international student flows.

\section{TABLE 3 NEAR HERE}

The ratio of GDP per capita in the destination country to the origin country is used to capture income differential effects on the expectation that if mean income in the destination exceeds mean income in the origin, all else equal, the incentive to migrate increases. The estimates reveal that the coefficient on the ratio of destination to origin country GDP per capita, though positively signed, is not statistically significant. This result is in line with previous results reported by Beine et al. (2014) who also found no significant effect between skill prices at destination and international student flows. Similar results were also found by Bessey (2012) who showed that higher GDP per capita did not exert any influence on international student inflows to Germany.

Consistent with expectations, countries that are further apart have smaller international student flows. The estimated coefficient for $\ln \left(\right.$ dist $\left._{\text {od }}\right)$ suggests a $10 \%$ increase in bilateral distance is on average associated with a $6.6 \%$ reduction in the volume of student flows. This result is consistent with the hypothesis that the costs of studying abroad are higher the greater

\footnotetext{
${ }^{12}$ Although there are no zero values in our dependent variable, PPML is less affected by heteroscedasticity than other estimators (Santos Silva and Tenreyo, 2006).

${ }^{13}$ While not reported to conserve space, closer examination of the individual country of origin and destination fixed effects, yields some interesting findings. For example, the dummy variables for most of the English speaking countries of destination (Australia, Canada, New Zealand, UK and USA) are all statistically significant and have positively signed estimated coefficients as expected. Among the countries of destination where English is not an official language, Germany appears to be a particularly attractive destination.
} 
the geographical distance between the origin and destination countries. This distance elasticity is less than that found for other trade flows, which range from -0.9 to -1.5 (Disdier and Head, 2008).

Turning to the other variables, countries that share a common land border are shown not to have larger student flows than non-contiguous countries. However, the common language variable is statistically significant. The coefficient on $\operatorname{lang}_{\text {od }}$ suggests that student flows are more than double between countries that speak the same language than those who speak different languages. ${ }^{14}$ This effect is consistent with expectations which suggest that sharing the same language lowers the cost of studying abroad. By contrast, colonial history plays no important role in determining international student flows. Previous work by Barnett and Wu (1995) analysing student exchange networks in 1970 and 1989 documented the declining importance of colonial linkages over time. Membership of the European Union (EU) as captured by an EU/non-EU origin dummy is positive and statistically significant indicating that EU-member countries experience 118\% higher bilateral student flows than non-EU countries. The higher rate of student mobility in the EU is largely due to the Erasmus exchange programmes. Unsurprising, the coefficient on the total number of students abroad from the country of origin is statistically significant and the estimated coefficient positively signed as expected. The coefficient on $\ln \left(\right.$ Outbd $\left._{o t}\right)$ implies that a $10 \%$ increase in the outflow of students raises bilateral student flows by $9.3 \%$.

Surprisingly, $\ln \left(r a n k_{d t}\right)$ is found to be unimportant in explaining international student flows. In recent work, Perkins and Neumayer (2014) found that countries' university rank had only a modest impact on the pattern of international student flows. Additionally, the

\footnotetext{
${ }^{14}$ In a separate analysis not reported, but available from the authors upon request, we replace lang $_{\text {od }}$ with two dummy variables that equal unity: i) when the country pairs share the English language in common; ii) where the common language is not English. We find the common English language dummy variable is statistically significant, with an estimated coefficient (t-statistic) of 0.732 (5.69), while for the other common languages, the dummy variable is statistically significant and the estimate (t-statistic) equals 1.788 (18.56).
} 
bilateral exchange rate is statistically insignificant. This last result may be rationalized by the fact that exchange rate fluctuations tend to be reduced by the availability of good hedging instruments.

\section{TABLE 4 NEAR HERE}

The above analysis provides important insights into the determinants of student mobility, particularly highlighting the variation in student flows across countries. The incentives to study abroad, as well as the available opportunities, are likely to vary across countries of origin and it is conceivable that the impact of our variables might depend on differences in income levels. For example, the cost of travel and subsistence to study abroad is a barrier to student mobility but even more so for students originating from non-high income countries. Table 4 shows the results of our model for high income countries and nonhigh income countries of origin, separately. The first column reports the results based on the subsample of high income countries ${ }^{15}$ and the second column reports estimates based on the subsample of non-high income countries. ${ }^{16}$ We observe that the fit of our model is much larger for non-high income countries than high income countries, with an R-squared of 0.90 and 0.96 respectively. Also the magnitude, sign and significance of a number of variables differ somewhat in the two subsamples of countries.

The GDP per capita ratio, which is used as a proxy for the wage differential, is positive and statistically significant only for non-high income countries. For these countries, the estimated coefficient indicates that a doubling of GDP per capita in the destination country relative to the origin leads to a $7.3 \%$ increase in international student flows. These results

\footnotetext{
${ }^{15}$ The group of high income countries are chosen from the World Bank's income classification (see http://data.worldbank.org/about/country-classifications). These are Australia, Austria, Belgium, Canada, Czech Republic, Estonia, Finland, France, Germany, Denmark, Greece, Iceland, Ireland, Israel, Italy, Japan, Korea, Netherlands, Norway, New Zealand, Portugal, Slovenia, Spain, Sweden, Switzerland, United Kingdom, and the United States.

${ }^{16}$ The group of non-high income countries include Argentina, Brazil, Chile, China, Hungary, India, Indonesia, Mexico, Poland, and Russia.
} 
imply that higher income in the destination country leads to an increase in student flows from non-high income countries. For students from these countries, one explanation is that access to better labour market opportunities increases the expected returns from studying abroad. These results are consistent with the predictions of the wealth-maximisation hypothesis outlined by Borjas $(1987,1992)$, which states that students will acquire schooling abroad as a means of entering and staying in the foreign country when there is a large wage gap between a pair of countries. For high income countries, the GDP per capita ratio is not statistically significant, though positively signed. The absence of a statistically significant effect for high income countries is likely to be caused by the fact that income levels may reflect the ability of a country to finance education abroad, apart from being a proxy for wage disparities (Rosenzweig, 2006). Presumably, a high-income origin country would send more students abroad, all else equal. In non-high income countries, the mobility constraint imposed by lower levels of income may be outweighed by more unequal income distributions within these countries, which allow those from wealthy backgrounds to afford the cost of studying abroad.

The results for distance confirm the conjecture that geographical distance is much less important for high-income countries than for non-high income countries. Specifically, for high-income countries, the estimates predict that a $10 \%$ increase in bilateral distance is on average associated with a 5.1\% reduction in the volume of student flows. For non-high income countries, the equivalent reduction is $12.6 \%$. These different effects for distance in different income groups are consistent with the findings of Brun et al. (2005) who found that the impact of distance on bilateral trade is much greater for low-income countries. The finding that distance effects for students from high-income countries are lower is most likely due to their superior transport infrastructures which lower costs of international travel. 
The results reveal that geographical contiguity is a characteristic that matters only for our set of high income countries. For high income countries, the estimates predict that international student flows between two countries that are contiguous are on average 37\% larger than between countries that do not share a border. This result is consistent with the expectation that sharing a common border implies a reduction in the cost of mobility faced by international students. For non-high income countries, adjacency has no significant effect on facilitating international student mobility. The lack of a statistically significant effect on contiguity probably arises because of the geographical dispersion of countries in this subcategory.

The coefficients on common language are positively signed, relatively large and statistically significant for both subsamples of countries but considerably larger for non-high income countries. For high income countries, the results predict that student flows between pairs of countries that share a common language are $211 \%$ larger than between those who do not speak the same language. For non-high income countries, the corresponding estimate is 367\%. These results suggest that international students from non-high income countries have a stronger preference to study in countries that speak the same language as their own while students from high-income countries are less deterred by linguistic differences to study abroad. Common colonial ties are not shown to enhance international student flows for either high income countries or non-high income countries. The total number of outbound students from the country of origin is positive and statistically significant for both high and non-high income countries. The results for high income countries suggest that a $10 \%$ increase in the number of students studying anywhere overseas will raise bilateral flows by $8.6 \%$. The equivalent figure for non-high income countries is markedly larger at $24.5 \%$.

For high income countries, university rank has no significant influence on student flows. The implication of this finding is that destinations that have better than average 
academic credentials do not appear to attract more students from high income countries. In contrast, for non-high income countries, the coefficient on rank is unexpectedly positive and statistically significant. Recall that higher ratings indicate lower rank. Therefore, the positive coefficient suggests an increase in student flows. This result is somewhat counterintuitive and hence difficult to interpret but may be explained by rank reflecting the costs of the decision to migrate for education; countries with low average ranking universities have significantly lower fees than countries with high average ranking universities. Our findings contrast with prior work by Beine et al. (2014) who showed that, controlling for university fees, students gravitate towards countries with higher university rankings.

\section{TABLE 5 NEAR HERE}

To date the gravity model has only considered the effect of physical distance on international trade. Distance has long been interpreted as a good proxy for both monetary and psychic costs of cross board mobility. However, as well as physical distance, the difference in time zones between a pair of countries could also be considered just as important for student mobility, particularly when students wish to maintain contact with their home country while studying abroad. ${ }^{17}$ Our measure of time difference is the number of overlapping daylight hours between each pair of countries' capital cities. This variable varies from zero to 12 . This definition, which is somewhat arbitrary, was chosen as we expect the greater the daylight time difference between two countries the lower the level of communication. Advances in information and communication technology have almost completely eliminated the monetary cost of maintaining contact with one's family from anywhere in the world. However, the ability to communicate at low cost should not make time difference irrelevant. The impact of time difference on the misalignment of daily schedules between families and students is

\footnotetext{
${ }^{17}$ Stein and Daude (2007) find that time zone differences have a significant and negative effect on the stock of foreign direct investment, while Portes and Rey (2005) find a negative influence on the determination of bilateral equity flows.
} 
likely to pose specific challenges for communication which go well beyond a pure monetary cost component. The psychic cost of real-time interaction associated to differences in time zones should be larger the narrower the time window available for communication. In this sense, even when communication costs are entirely zero, technology cannot overcome the problems of real time interaction when time zones are very different. Given the nature of family communication, time zone proximity between locations is likely to substantially lower the psychic cost of studying abroad. In fact, time distance may pose more challenges than geographical distance for communication between family members. To allow for this hypothesis, we re-estimated our gravity model replacing physical distance with a variable that measures differences between time zones.

The results from this specification are reported in table 5. Our estimates confirm a time difference effect which is unique to this literature in that it is the first to identify the importance of time zones for international student mobility. The $\ln \left(\right.$ time $_{\text {od }}$ ) variable is statistically significant, negatively signed and virtually identical for both subsamples of countries. The estimated coefficients for high income countries indicate that a $10 \%$ increase in time difference between two countries reduces international student flows by $6.4 \%$. For non-high income countries the equivalent reduction is almost 7\%. These results suggest that time difference is a deterrent to the movement of students across borders, which is approximately the same for students from both sets of countries. This similarity of estimates follows from the intuition that students from high income countries should be affected by the psychic cost of communication in the same way as those from non-high income countries. Also, these results reconcile with the view that while technology-driven reductions in the cost of communication have occurred, the coefficient on time difference should be no stronger for students from either high-income or non-high income countries. In comparison with the 
estimates for distance, for high income countries, the estimate for time difference turns out to be similar in magnitude to that for physical distance. In contrast, for non-high income countries, the estimates suggest that physical distance plays a much bigger role than time difference. ${ }^{18}$ The results from all other parameters in our model are generally robust to the use of time zone differences, though the coefficient on the GDP per capita ratio is no longer statistically significant for non-high income countries.

\section{Conclusion}

Gravity models have long been estimated to model trade in goods and services, foreign direct investment, international portfolio investment, factor movements, and immigration. This paper applies the gravity model to international student flows. Using data for 18 countries of destination and 38 countries of origin over the period 2005-2011, we augment the gravity model with additional variables that are potentially important drivers of international student mobility and analyse our sample disaggregated by countries of origin income level.

Furthermore, unlike the previous literature, we replace physical distance with time zone difference in our gravity equation, to examine the hypothesis that countries tend to exchange more students the smaller the time difference between the origin and the country of destination.

The good fit of our specification suggests that international student flows are well described by our model. An important insight from our study is that splitting the overall sample by income level reveals significant differences in coefficient estimates for non-high

\footnotetext{
${ }^{18}$ In our sample, there is a high correlation between geographical distance and time zone differences. The correlation between geographical distance and time difference equals 0.93 for high income countries and 0.53 for non-high income countries. In additional unreported work, both distance and time difference were included simultaneously in the same regression to allow distance and time to have separate effects on international student flows, holding all other factors constant. This sensitivity check finds that physical distance is far more important than time difference for students from non-high income countries whereas time difference turns out to be far more important than physical distance for students from high income countries.
} 
income countries compared with high-income countries. For non-high income countries the results indicate that much of the flow of international students is attributable to higher per capita income in destination countries. For high income countries the ratio of per capita GDP between countries of destination and origin is not statistically significant. These results are consistent with the hypothesis that the benefits of migration for students who originate from poorer countries are higher than for wealthier countries, and therefore that those from economically disadvantaged countries have the most incentive to study abroad. Countries that speak the same language have much larger flows of international students than countries that do not share the same language. For non-high income countries these linkages play a much larger role in advancing the exchange of students than is the case for high-income countries. International student mobility is also found to be inversely proportional to geographical distance. However, our results reveal that distance has a much more pronounced effect for non-high income countries than for high income countries. The implication of this finding is that students originating in low and middle income countries are much more constrained in their educational choices by physical distance. A major contribution of our paper has been to evidence that international time differences substantially reduce international student flows. Unlike the effect of physical distance, the impact of time proximity is remarkably similar for both high-income and non-high income countries. Consequently, destination countries tend to be more exposed to competition from other countries in proximate time zones, other things equal. 


\section{References}

Altbach, P., 2007. The imperial tongue: english as the dominating academic language. Economic and Political Weekly 42, 3608-3611.

Anderson, J., Van Wincoop, E., 2004. Trade costs. Journal of Economic Literature 42, 691-751.

Barnett G., Wu, R. 1995. The international student exchange network: 1970 \& 1989. Higher Education 30, 353-368.

Bergstrand, J., 1985. The gravity equation in international trade: some microeconomic foundations and empirical evidence. Review of Economics and Statistics 67, 474-481.

Bertoli, S., Fernández-Huertas Moraga, J., 2013. Multilateral resistance to migration. Journal of Development Economics 102, 79-100.

Bertoli, S., Fernández-Huertas Moraga, J., 2015. The size of the cliff at the border. Regional Science and Urban Economics 51, 1-6.

Bessey, D., 2012. International student migration to Germany. Empirical Economics 42, 345-361.

Beine, M., Noël, R., Ragot, L., 2014. The determination of international mobility of students, Economics of Education Review 41, 40-54.

Beine, M., Bertoli, S., Fernández-Huertas Moraga, J., 2015. A practitioners’ guide to gravity models of international migration. The World Economy (forthcoming; doi: 10.1111/twec.12265).

Borjas, G., 1987. Self-selection and the earnings of immigrants. American Economic Review 77, 531-553.

Borjas, G., 1992. Immigration and self-selection. In: Freeman, R., Abowd, J. (Eds.) Immigration, Trade, and the Labor Market. Chicago: University of Chicago Press. 
Brun, J., Carr`ere, C., de Melo, J. and Guillaumont, P., 2005. Has distance died? Evidence from a panel gravity model. World Bank Economic Review 19, 99-120.

Cavanagh, M., Glennie, A., 2012. International students and net migration in the UK. IPPR Report. Access online at http://www.ippr.org/assets/media/images/media/files/publication/2012/04/internationalstudents-net-migration_Apr2012_8997.pdf

Chiswick, B., Miller, P., 2011. Educational mismatch: are highly-skilled immigrants really working in high-skilled jobs, and what price do they pay if they are not? In: B. Chiswick (Ed.) High-Skilled Immigration in a Globalised Labour Market. Washington DC: American Enterprise Institute.

Deardorff, A., 1998. Determinants of bilateral trade: does gravity work in a classical world? In: J. A. Frankel (Ed.) Regionalization of the World Economy. Chicago: University of Chicago Press.

Disdier, A., Head, K., 2008. The puzzling persistence of the distance effect on bilateral trade. Review of Economics and Statistics 90, 37-48.

Disdier, A., Mayer, T., 2007. Je t’aime, moi non plus: bilateral opinions and international trade. European Journal of Political Economy 23, 1140-1159.

Dreher, A., Poutvaara, P., 2005. Student flows and migration: an empirical analysis. IZA Discussion Paper No. 1612.

Head, K., Mayer, T., 2013. Gravity equations: workhorse, toolkit, and cookbook. CEPII working paper No. 2013-27.

Kahanec, M., Králiková, R., 2011. Pulls of international student mobility, IZA Discussion Paper No. 6233, IZA, Bonn.

Lewer, J., Van den Berg, H., 2008. A gravity model of immigration. Economics Letters 99, 164-167. 
Linders, G., 2006. Intangible barriers to trade: the impact of institutions, culture and distance on pattern of trade. Tinbergen Institute Research Series No. 371, Tinbergen Institute.

Mayda, A., 2010. International migration: a panel data analysis on the determination of bilateral flows. Journal of Population Economics 23, 1249-1274.

Mayer, T., Zignago, S., 2011. Notes on CEPII’s distances measures: the GeoDist database. CEPII Working Paper No. 2011-05.

OECD, 2013. Education at a glance. Paris: Organisation for Economic Cooperation and Development.

Perkins, R., Neumayer, E. 2014. Geographies of educational mobilities: exploring the uneven flows of international students. The Geographic Journal 180, 246-259.

Portes, R., Rey, H., 2005. The determinants of cross-section border equity flows. Journal of International Economics 65, 269-296.

Rosenzweig, M., 2006. Global wage differences and international student flows. Brookings Trade Forum, 57-86.

Santos Silva, J. M. C and Tenreyro, S., 2006. The log of gravity. Review of Economics and Statistics 88, 4, 641-658.

Santos Silva, J. M. C and Tenreyro, S., 2011. Further simulation evidence on the performance of the Poissan Pseudo-Maximum Likelihood estimator. Economics Letters 112, 220-222.

Simpson, N. and Sparber, C., 2013. The short-run and long-run determinants of less-educated immigrant flows into U.S. States. Southern Economic Journal 80, 414-438.

Stein, E., Daude, C. (2007). Longitude matters: tiem zones and the location of foreign direct investment. Journal of International Economics 71, 96-112.

Varghese, N. 2008. Globalization of higher education and cross-border student mobility. Research paper, International Institute for Educational Planning. 
Zheng, J., 2010. Neoliberal globalization, higher education policies and international student flows: an exploratory case study of Chinese graduate student flows to Canada. Journal of Alternative Perspectives in the Social Sciences 2, 216-244. 


\section{Appendix A}

Description of variables

\begin{tabular}{|c|c|c|}
\hline Variable & Description & Source \\
\hline$S_{\text {od }}$ & $\begin{array}{l}\text { Number of students from country of origin } o \\
\text { studying in country of destination } d\end{array}$ & $\begin{array}{l}\text { OECD Education at a } \\
\text { Glance, various issues }\end{array}$ \\
\hline $\begin{array}{c}G D P p c_{o} \\
\left(G D P p c_{d}\right)\end{array}$ & $\begin{array}{l}\text { Gross domestic product per capita of country of } \\
\text { origin (destination) in constant } 2005 \text { US dollars }\end{array}$ & $\begin{array}{l}\text { World Bank World } \\
\text { Development Indicators }\end{array}$ \\
\hline dist $_{o d}$ & $\begin{array}{l}\text { Great circle distance in kilometres between the two } \\
\text { countries of origin and destination, using the most } \\
\text { important city (in terms of population) or the } \\
\text { official capital. }\end{array}$ & $\begin{array}{l}\text { Mayer and Zignago } \\
\text { (2011) }\end{array}$ \\
\hline cont $_{\text {od }}$ & $\begin{array}{l}\text { A binary variable that equals unity whenever both } \\
\text { countries share the same land border }\end{array}$ & $\begin{array}{l}\text { Mayer and Zignago } \\
\text { (2011) }\end{array}$ \\
\hline lang $_{\text {od }}$ & $\begin{array}{l}\text { A binary variable that equals unity whenever a } \\
\text { language is spoken by at least } 9 \% \text { of the population } \\
\text { in both countries }\end{array}$ & $\begin{array}{l}\text { Mayer and Zignago } \\
\text { (2011) }\end{array}$ \\
\hline colod $_{\text {od }}$ & $\begin{array}{l}\text { A binary variable that equals unity for country pairs } \\
\text { that have ever been in a colonial relationship }\end{array}$ & $\begin{array}{l}\text { Mayer and Zignago } \\
\text { (2011) }\end{array}$ \\
\hline$E U_{o d}$ & $\begin{array}{l}\text { A binary variable that equals unity for country pairs } \\
\text { that are EU members }\end{array}$ & \\
\hline $\operatorname{rank}_{d t}$ & Mean institutional ranking in country of destination & $\begin{array}{l}\text { QS World University } \\
\text { ranking }\end{array}$ \\
\hline outbd $_{o t}$ & $\begin{array}{l}\text { The total number of students studying abroad from } \\
\text { the country of origin for tertiary education }\end{array}$ & $\begin{array}{l}\text { World Bank Educational } \\
\text { Statistics }\end{array}$ \\
\hline$R E R_{o d}$ & $\begin{array}{l}\text { The real exchange rate, defined as the origin } \\
\text { currency's value of one unit of a given destination's } \\
\text { currency, multiplied by the destination country's } \\
\text { GDP deflator and divided by the origin countries } \\
\text { GDP deflator. }\end{array}$ & $\begin{array}{l}\text { World Bank World } \\
\text { Development Indicators }\end{array}$ \\
\hline time $_{\text {od }}$ & $\begin{array}{l}\text { Number of overlapping daylight hours between the } \\
\text { capital cities of country pairs. }\end{array}$ & Britannica Atlas \\
\hline
\end{tabular}


Table 1 Countries of Origin, 2005-2011

\begin{tabular}{lcc}
\hline & Number of students & Flow as \% of Total \\
\hline China & $1,637,411$ & 29.25 \\
India & 917,672 & 16.39 \\
Korea & 478,033 & 8.54 \\
Germany & 286,244 & 5.11 \\
Japan & 278,271 & 4.97 \\
France & 226,252 & 4.04 \\
Canada & 224,814 & 4.02 \\
USA & 195,664 & 3.50 \\
Poland & 139,125 & 2.49 \\
Mexico & 120,373 & 2.15 \\
Total (for 38 countries) & $5,597,708$ & \\
Source: OECD Education at a Glance, various issues &
\end{tabular}

Table 2 Countries of Destination, 2005-2011

\begin{tabular}{ccc}
\hline & Number of students & Flow as \% of Total \\
\hline USA & $2,525,487$ & 45.12 \\
UK & 814,909 & 14.56 \\
Australia & 690,152 & 12.33 \\
Germany & 645,721 & 11.54 \\
Canada & 221,829 & 3.96 \\
Switzerland & 128,822 & 2.30 \\
New Zealand & 123,403 & 2.20 \\
Spain & 103,151 & 1.84 \\
Netherlands & 90,337 & 1.61 \\
Sweden & 75.024 & 1.34 \\
Total (for 38 countries) & $5,597,708$ & \\
Source: OECD Education at $a$ Glance, various issues &
\end{tabular}


Table 3 Gravity Model of International Student Flows

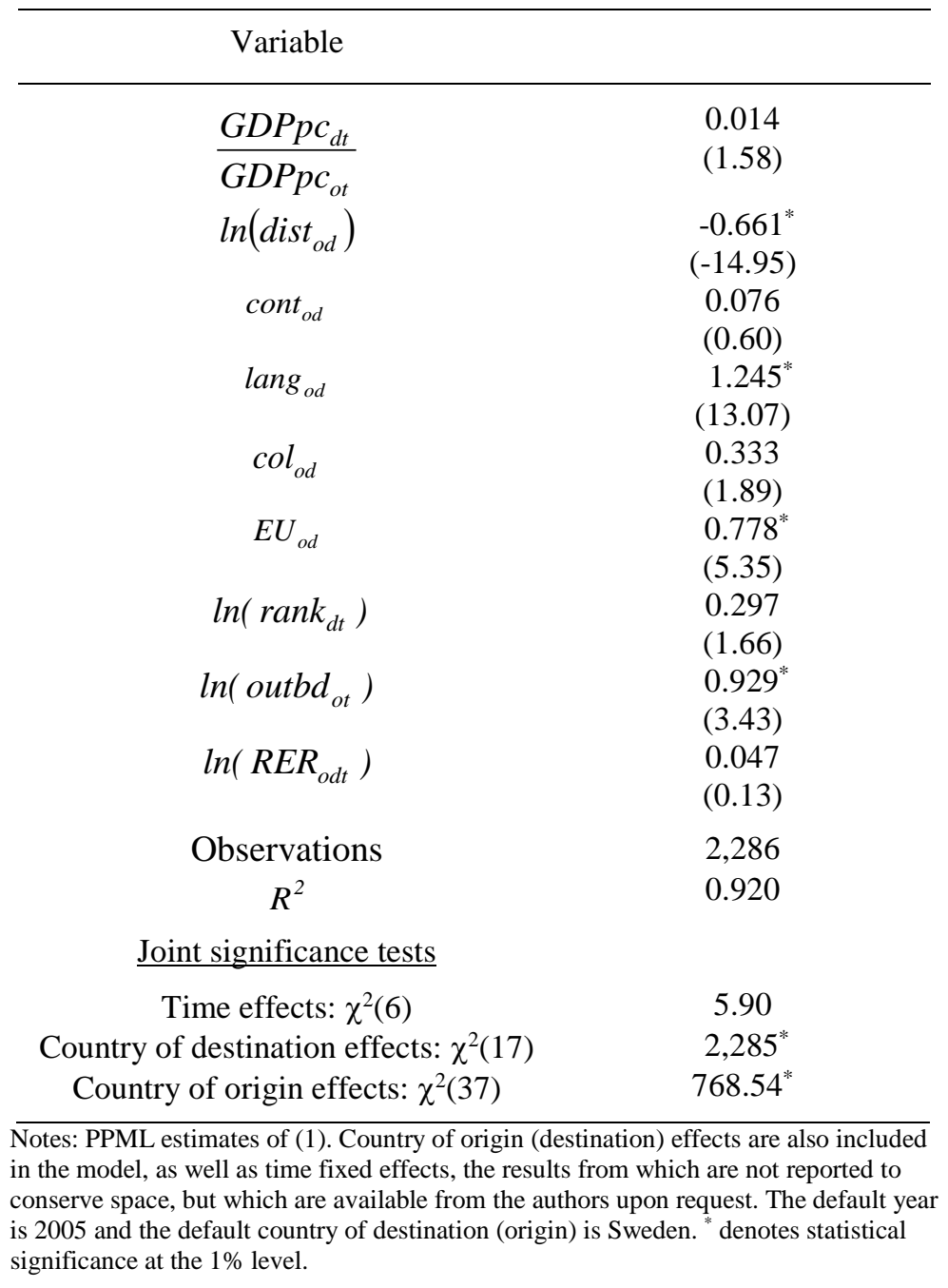


Table 4 Gravity Model of International Student Flows by Country Income Group

\begin{tabular}{|c|c|c|}
\hline Variable & High Income & Non-High Income \\
\hline$\frac{G D P p c_{d t}}{G D P p c_{c t}}$ & $\begin{array}{l}0.269 \\
(1.15)\end{array}$ & $\begin{array}{l}0.073^{*} \\
(6.08)\end{array}$ \\
\hline $\ln \left(\right.$ dist $\left._{o d}\right)$ & $\begin{array}{l}-0.512^{*} \\
(-9.38)\end{array}$ & $\begin{array}{c}-1.261^{*} \\
(-13.83)\end{array}$ \\
\hline cont $_{\text {od }}$ & $\begin{array}{l}0.315^{* *} \\
(2.36)\end{array}$ & $\begin{array}{l}-0.379 \\
(-1.27)\end{array}$ \\
\hline lang $_{\text {od }}$ & $\begin{array}{l}1.136^{*} \\
(9.91)\end{array}$ & $\begin{array}{l}1.542^{*} \\
(9.90)\end{array}$ \\
\hline $\mathrm{col}_{\text {od }}$ & $\begin{array}{r}0.242 \\
(1.89)\end{array}$ & $\begin{array}{l}0.096 \\
(0.54)\end{array}$ \\
\hline$E U_{\text {od }}$ & $\begin{array}{l}0.899^{*} \\
(5.94)\end{array}$ & $\begin{array}{l}-0.0006 \\
(-0.01)\end{array}$ \\
\hline $\ln \left(\operatorname{rank}_{d t}\right)$ & $\begin{array}{l}0.050 \\
(0.21)\end{array}$ & $\begin{array}{l}0.427^{*} \\
(2.65)\end{array}$ \\
\hline $\ln \left(\right.$ outbd $\left._{o t}\right)$ & $\begin{array}{l}0.864^{*} \\
(3.24)\end{array}$ & $\begin{array}{l}2.445^{*} \\
(4.11)\end{array}$ \\
\hline $\ln \left(R E R_{o d t}\right)$ & $\begin{array}{l}0.232 \\
(0.64)\end{array}$ & $\begin{array}{l}-0.516 \\
(-1.27)\end{array}$ \\
\hline Observations & 1,720 & 566 \\
\hline$R^{2}$ & 0.897 & 0.962 \\
\hline \multicolumn{3}{|l|}{$\underline{\text { Joint significance tests }}$} \\
\hline $\begin{array}{l}\text { Time effects: } \chi^{2}(6) \\
\text { Country of destination effects: } \chi^{2}(17) \\
\text { Country of origin effects: } \chi^{2}(37)\end{array}$ & $\begin{array}{c}7.69 \\
2,180^{*} \\
437^{*}\end{array}$ & $\begin{array}{c}6.04 \\
4,164^{*} \\
236^{*}\end{array}$ \\
\hline
\end{tabular}

Notes: PPML estimates of (1). Country of origin (destination) effects are also included in the model, as well as time fixed effects, the results from which are not reported to conserve space, but which are available from the authors upon request. The default year is 2005, the default country of destination is Sweden, and the default country of origin among high income countries is also Sweden and Indonesia among non-high income countries. ${ }^{*}$ denotes statistical significance at the $1 \%$ level; ${ }^{* *}$ denotes statistical significance at the $5 \%$ level. 
Table 5 Gravity Model of International Student Flows incorporating time difference

\begin{tabular}{|c|c|c|}
\hline Variable & High Income & Non-High Income \\
\hline$G D P p c_{d t}$ & 0.069 & 0.016 \\
\hline$\overline{G D P p c_{o t}}$ & & \\
\hline $\ln \left(\right.$ time $\left._{o d}\right)$ & $\begin{array}{l}-0.644^{*} \\
(-9.26)\end{array}$ & $\begin{array}{l}-0.697^{*} \\
(-9.38)\end{array}$ \\
\hline cont $_{\text {od }}$ & $\begin{array}{c}0.583^{*} \\
(4.14)\end{array}$ & $\begin{array}{l}0.023 \\
(0.11)\end{array}$ \\
\hline lang $_{\text {od }}$ & $\begin{array}{l}1.029^{*} \\
(8.47)\end{array}$ & $\begin{array}{l}1.410^{*} \\
(9.40)\end{array}$ \\
\hline $\mathrm{Col}_{\text {od }}$ & $\begin{array}{c}0.179 \\
(1.45)\end{array}$ & $\begin{array}{l}0.413 \\
(3.23)\end{array}$ \\
\hline$E U_{\text {od }}$ & $\begin{array}{c}0.708^{*} \\
(5.28)\end{array}$ & $\begin{array}{l}0.422^{* *} \\
(2.08)\end{array}$ \\
\hline $\ln \left(\operatorname{rank}_{d t}\right)$ & $\begin{array}{l}0.055 \\
(0.23)\end{array}$ & $\begin{array}{l}0.451^{* * *} \\
(2.01)\end{array}$ \\
\hline $\ln \left(\right.$ outbd $\left.d_{o t}\right)$ & $\begin{array}{c}0.872^{*} \\
(3.41)\end{array}$ & $\begin{array}{l}1.177^{* *} \\
(2.06)\end{array}$ \\
\hline $\ln \left(R E R_{\text {odt }}\right)$ & $\begin{array}{l}0.158 \\
(0.45)\end{array}$ & $\begin{array}{l}-0.143 \\
(-0.45)\end{array}$ \\
\hline Observations & 1,720 & 566 \\
\hline$R^{2}$ & 0.906 & 0.973 \\
\hline \multicolumn{3}{|l|}{$\underline{\text { Joint significance tests }}$} \\
\hline Time effects: $\chi^{2}(6)$ & 8.90 & 4.98 \\
\hline Country of destination effects: $\chi^{2}(17)$ & $1,988^{*}$ & $3251^{*}$ \\
\hline Country of origin effects: $\chi^{2}(37)$ & $468^{*}$ & $94.2^{*}$ \\
\hline
\end{tabular}

Notes: PPML estimates of (1). Country of origin (destination) effects are also included in the model, as well as time fixed effects, the results from which are not reported to conserve space, but which are available from the authors upon request. The default year is 2005, the default country of destination is Sweden, and the default country of origin among high income countries is also Sweden and Indonesia among non-high income countries. ${ }^{*}$ denotes statistical significance at the $1 \%$ level; ${ }^{* *}$ denotes statistical significance at the $5 \%$ level. 